JURNAL KETAHANAN NASIONAL

Vol.23, No.2, Agustus 2017, Hal 238-260

DOI:http://dx.doi.org/10.22146/jkn.25929

ISSN:0853-9340(Print), ISSN:2527-9688(Online)

Online sejak 28 Desember 2015 di :http://jurnal.ugm.ac.id/JKN

VOLUME 23

No. 2, Agustus 2017

Halaman 238-260

\title{
Ketahanan Kawasan Wisata Berbasis Masyarakat Dalam Penguatan Ekonomi Lokal Dan Pelestarian Sumberdaya Kebudayaan Kawasan Kotagede Yogyakarta
}

\author{
Wenang Anurogo \\ Jurusan Teknik Informatika, Program Studi Teknik Geomatika, Politeknik Negeri Batam, \\ Batam Kota, Kepulauan Riau, 29461 Indonesia \\ email: wenang@polibatam.ac.id (official email) \\ Muhammad Zainuddin Lubis \\ Jurusan Teknik Informatika, Program Studi Teknik Geomatika, Politeknik Negeri Batam, \\ Batam Kota, Kepulauan Riau, 29461 Indonesia \\ email: zainuddinlubis@polibatam.ac.id (official email)
}

\begin{abstract}
Hartono
Jurusan Sistem Informasi Geografi dan Pembangunan Wilayah, Program Studi Kartografi dan Penginderaan jauh Universitas Gadjah Mada, Sekip Utara, 55281 Yogyakarta, Indonesia. email: hartonogeografi@geo.ugm.ac.id (official email)

Daniel Sutopo Pamungkas

Jurusan Teknik Elektro, Program Studi Teknik Elektro, Politeknik Negeri Batam, Batam Kota, Kepulauan Riau, 29461 Indonesia email: daniel@polibatam.ac.id (official email)

\author{
Ahmad Prasetya Dilaga \\ Mahasiswa Program Studi Pembangunan Wilayah Universitas Gadjah Mada, Sekip Utara, \\ 55281 Yogyakarta, Indonesia \\ email: ahmadprasetyadilaga@gmail.com (official email)
}

\begin{abstract}
Kotagede Cultural Heritage area had been considered less attention. The tour trail activity was able to provided historical, fun and healthy knowledge as it could only be preserved or on foot. The activity depended on the interest of the people and tourists in choosing the tour. This research was intended to contributed to the objective analysis in one of the important destinations in Yogyakarta City which was the cultural art and heritage of Kotagede and provided a spatial picture of the existing cultural tourism attractions to provided informative knowledge to the public to be in demand and continue to preserved the tour.

The study of Kotagede tourism object used qualitative method combined with the use of high-resolution remote sensing image data in more interactive visualization results.
\end{abstract}


Wenang Anurogo, Muhammad Zainuddin Lubis, Hartono, Daniel Sutopo Pamungkas, Ahmad Prasetya Dilaga -- Ketahanan Kawasan Wisata Berbasis Masyarakat dalam Penguatan Ekonomi Lokal dan Pelestarian

Sumberdaya Kebudayaan Kawasan Kotagede Yogyakarta

The result of Kotagede tourism study showed that tourism object in Kotagede Culture area was cultural object, tradition, craft, and art which was summarized into four recommended route that were spiritual trail tour package, hallway trail tour package, architectural trail tour package, and study trail tour package. Managed in a participatory manner by the surrounding community and could still grew better if received direct attention from the government and stakeholders related to the management of the tourist area of Kotagede.

\title{
Keywords: Kotagede, Heritage Trail, High-Resolution Image Data, Tourism Area Resilience
}

\begin{abstract}
ABSTRAK
Kawasan Cagar Budaya (KCB) Kotagede selama ini dinilai kurang mendapat perhatian. Kegiatan tour wisata heritage trail ini mampu memberi pengetahuan sejarah, menyenangkan, dan menyehatkan karena hanya dapat dilalui dengan bersepeda atau berjalan kaki. Kegiatan tersebut tergantung dari minat masyarakat dan wisatawan dalam memilih tour wisata. kajian ini dimaksudkan untuk turut memberikan kontribusi dalam analisis destinasi di salah satu tujuan penting di Kota Yogyakarta yaitu kawasan seni budaya dan heritage Kotagede dan memberikan gambaran spasial tentang atraksi wisata budaya yang ada di sana guna memberikan pengetahuan yang informatif kepada masyarakat agar tertarik dan terus bisa melestarikan wisata tersebut.

Kajian objek wisata heritage trail di Kotagede ini menggunakan metode kualitatif ditambah dengan pemanfaatan data citra penginderaan jauh resolusi tinggi dalam visualisasi hasil yang lebih interaktif.

Hasil kajian wisata kawasan Kotagede menunjukkan bahwa atraksi wisata yang ada di kawasan Cagar Budaya Kotagede berupa benda-benda budaya, tradisi, kerajinan, dan kesenian yang dirangkum ke dalam empat rute yang direkomendasikan yakni, paket wisata jelajah spiritual, paket wisata jelajah lorong, paket wisata jelajah arsitektural, dan paket wisata jelajah studi. Paket wisata tersebut dikelola secara partisipatif oleh masyarakat sekitar dan masih dapat berkembang menjadi lebih baik lagi apabila mendapat perhatian secara langsung dari pemerintah maupun stakeholder yang berkepentingan terkait dengan pengelolaan kawasan wisata Kotagede.
\end{abstract}

\section{Kata Kunci: Kotagede, Jelajah Warisan Kebudayaan, Data Citra Resolusi Tinggi, Pariwisata}

\section{PENGANTAR}

Indonesia mempunyai kekayaan alam dan kekayaan budaya tersebar ke seluruh penjuru negeri dari Sabang sampai Merauke. Negara Indonesia merupakan negara kepulauan, berbagai macam jenis wisata yang ada di negara ini, baik wisata alam yang menyajikan panorama alam maupun wisata kebudayaan pada masing masing daerah yang menyajikan keunikan budaya pada tiap wilayah yang ada di Indonesia. Industri pariwisata merupakan salah satu bidang yang mampu mempercepat pergerakan ekonomi di daerah, sehingga mampu mempercepat pertumbuhan dan pembangunan daerah. Manfaat industri pariwisata minimal mampu meningkatkan taraf ekonomi masyarakat daerah wisata. Secara tidak langsung pertumbuhan ekonomi di daerah wisata akan berpengaruh pada pembangunan nasional. Adanya berbagai obyek wisata akan meningkatkan devisa negara dan terserapnya tenaga kerja masyarakat di daerah (Andayani et al, 2017).

Destinasi di Indonesia sangat beragam berdasarkan karakter dari destinasi tersebut. Salah satu destinasi yang penting dan perlu mendapatkan perhatian adalah destinasi berbasis wisata budaya (Armawi et al, 2016). Hal ini penting mengingat pariwisata heritage (warisan) memiliki keterkaitan dengan berbagai aspek seperti pendidikan, sejarah dan kebudayaan.

Objek pariwisata budaya yang terkenal di Indonesia salah satunya terletak di Yogyakarta (Yusuf et al, 2016). Kotagede merupakan salah satu kecamatan di Kota Yogyakarta yang memiliki potensi industri wisata budaya dengan daya tarik cagar budaya Kerajaan 
Mataram. Melihat dari sisi fisik dan non-fisik, Kotagede cepat mengalami perubahan pada dua dasawarsa terakhir dengan maraknya pembangunan dan interaksi warganya dengan dunia luar. Gempa bumi yang terjadi pada 27 Mei 2006 memunculkan polemik dari para pemilik bangunan kuno. Pemilik bangunan berusaha merenovasi rumah agar bisa mempertahankan peninggalan masa lampau atau merubah arsitektur bangunannya agar lebih kuat. Sementara di sisi lain, cukup banyak pihak yang menginginkan potensi budaya Kotagede yang unik ini tetap dipertahankan dan dijadikan sebagai kawasan pariwisata.

Kotagede terletak sekitar 10 kilometer di sebelah Tenggara jantung Kota Yogyakarta. Wilayah itu sekarang terkenal dengan nama Kawasan Cagar Budaya (KCB) Kotagede yang diatur sesuai dengan Perda Prov DIY No. 11 tahun 2005 pasal 1 ayat 6 , yaitu sebagai kota tua bekas Ibukota Kerajaan Mataram Islam yang memiliki benda atau bangunan cagar budaya dan mempunyai karakteristik serta kesamaan latar belakang dalam batas geografis yang ditentukan dengan deliniasi fisik dan non fisik. KCB Kotagede juga merupakan kota warisan (heritage) yang amat berpotensi bagi kemakmuran masyarakatnya (Rahmi, 2011).

Kotagede adalah nama sebuah kota yang merupakan Ibukota Kerajaan Mataram Islam. Selanjutnya kerajaan itu terpecah menjadi Kesunanan Surakarta dan Kesultanan Yogyakarta. Wilayah Kecamatan Kotagede sebagian merupakan bagian dari bekas Kota Kotagede ditambah dengan daerah sekitarnya. Sedangkan bagian lain dari bekas Kota Kotagede berada di wilayah Kecamatan Banguntapan, Kabupaten Bantul. Kondisi seperti itu kadang-kadang menyulitkan untuk membangun Kotagede dalam konteks sebagai bekas kota yang masyarakatnya mempunyai kesatuan sosiologis dan antropologis. Sampai sekarang masyarakat bekas Kota Kotagede dalam kegiatan sosial sehari-hari masih sangat solid dalam kesatuan itu. Desa-desa di Kotagede masih memegang budaya gotongroyong, sehingga masih sering dijumpai kegiatan-kegiatan masal yang dimotori oleh pemuda.

Organisasi pemuda atau karang taruna menjadi cikal bakal lahirnya kegiatan dalam upaya meningkatkan promosi dan pelestarian cagar budaya. Terdapat dua organisasi pemuda yang mengusung Kotagede sebagai destinasi wisata dan mengemasnya ke dalam tour wisata. Desa Jagalan dengan tagline "Jagalan Tlisih Telusur Kampung Pusaka” dan Desa Prenggan dengan tagline "Jelajah Pusaka Kampung Wisata Prenggan". Masing-masing memiliki kemasan dan daya tarik tersendiri untuk menarik minat masyarakat dan wisatawan.

"Jagalan Tlisih Telusur Kampung Pusaka" merupakan program hasil kerjasama arsitek komunitas Yogyakarta (ArkomJogja), karangtaruna Desa Jagalan, dan AirAsia Foundation. Program tersebut mulai diresmikan pada bulan Maret 2015. Atraksi yang ditawarkan dengan mengemas kawasan wisata dengan menyusuri lorong perkampungan yang saling terhubung di Kotagede dengan menikmati perjalanan kota tua. "Jelajah Pusaka Kampung Wisata Prenggan" telah lebih dahulu berdiri dan secara aktif mengadakan promosi dan kegiatankegiatan tour wisata. Penandaan kawasan masih dapat dilihat secara fisik melalui berbagai situs bekas reruntuhan, maupun toponim nama-nama kawasan.

Kesulitan pembangunan oleh pemerintah muncul ketika penanganan dilakukan oleh 
Wenang Anurogo, Muhammad Zainuddin Lubis, Hartono, Daniel Sutopo Pamungkas, Ahmad Prasetya Dilaga -- Ketahanan Kawasan Wisata Berbasis Masyarakat dalam Penguatan Ekonomi Lokal dan Pelestarian

Sumberdaya Kebudayaan Kawasan Kotagede Yogyakarta

stakeholder pemerintah di tingkat Kota Yogyakarta dan Kabupaten Bantul. Pemerintah Kota Yogyakarta hanya mampu menyentuh wilayah bekas Kota Kotagede yang masuk wilayah Kota Yogyakarta. Demikian juga Pemerintah Kabupaten Bantul hanya wilayah yang masuk Kabupaten Bantul. Arsitektural kota tua di Kotagede merupakan peninggalan Mataram Islam Kotagede, di sini wisatawan diajak untuk mempelajari kembali aspekaspek arsitektural Kotagede termasuk budaya yang melingkupi dan mempengaruhinya. Artraksi arsitektural di Kotagede merupakan gambaran perkembangan dari masa ke masa yang terdiri dari situs peninggalan sejarah Kerajaan Mataram Islam Kotagede, rumahrumah adat Jawa, rumah joglo, rumah para saudagar kaya peninggalan masa kejayaan industri perak yang membentuk sebuah perkampungan dengan sendirinya (Octaviano, 2013). Kebijakan dalam pengelolaan secara makro maupun mikro perlu memperoleh perhatian, sehingga diharapkan pengembangan wisata warisan budaya tidak akan mencederai nilai-nilai budaya masyarakat itu sendiri dan memberikan manfaat baik secara ekonomi, sosial dan lingkungan. Oleh karena ini penelitian ini dimaksudkan untuk turut memberikan kontribusi dalam analisis destinasi di salah satu destinasi penting di Kota Yogyakarta yaitu kawasan seni budaya dan heritage Kotagede.

Kawasan Cagar Budaya (KCB) Kotagede selama ini dinilai kurang mendapat perhatian. Padahal, kawasan tersebut merupakan salah satu situs sarat sejarah dan budaya yang merupakan peninggalan Kerajaan Mataram Islam. Hal itulah yang mendorong Dinas Kebudayaan (Disbud) DIY membentuk Badan Pengelola Kawasan Cagar Budaya (KCB) Kotagede. Dengan menggandeng sejumlah elemen masyarakat dan pemangku jabatan terkait diharapkan keberadaan Badan Pengelola KCB itu bisa lebih optimal dalam upaya pelestarian situs warisan budaya Kotagede (Saleh \& Hardjasoemantri, 2004).

Sisi lain Kotagede merupakan salah satu daerah tujuan wisata di Yogyakarta. Kota ini sangat terkenal dalam hal kerajinan peraknya, juga nilai kesejarahannya yang banyak berhubungan dengan Kraton Kasultanan Yogyakarta. Akan tetapi, padatnya pemukiman penduduk di kawasan ini telah menimbulkan berbagai permasalahan. Secara tidak langsung mempengaruhi eksistensi benda-benda cagar budaya yang ada di kawasan ini. Di samping itu, dampak dari pemekaran kota juga merupakan ancaman tersendiri bagi keberadaan benda-benda budaya, karena dapat menyebabkan ketidakseimbangan antara daya dukung lingkungan dan situs, dengan beban kawasan, erosi, dan polusi. Berdasarkan kondisi tersebut terlihat bahwa belum ada pengelolaan potensi kawasan secara terpadu, padahal Kotagede cukup potensial untuk dijadikan salah satu tujuan wisata unggulan. Penduduk yang sebagian besar pengrajin, merupakan wujud usaha mandiri warga Kotagede dalam menambah penghasilan untuk keluarga (Suprihanto \& Armawi, 2016).

Kegiatan tour wisata ini mampu memberi pengetahuan sejarah, menyenangkan, dan menyehatkan karena hanya dapat dilalui dengan bersepeda atau berjalan kaki. Kegiatan tersebut tergantung dari minat masyarakat dan wisatawan dalam memilih tour wisata (Ristiyanti, 2008). Pengelola yang didominasi oleh aktifis Karang Taruna ini diharapkan mampu mempromosikan dan meningkatkan minat wisatawan (Gafara et al, 2017), sehingga menjadikan trend heritage trail sebagai destinasi utama. Ketersediaan sarana 
dan prasarana yang memadai seperti jalan, toilet, lampu penerangan, papan penunjuk jalan untuk sampai ke Kotagede sudah cukup memadai. Pembagian rute dan perkiraan waktu menjadi dasar pertimbangan pengelola dalam menentukan paket-paket jelajah dengan berbagai macam modifikasi (Handayani, \& Priyono, 2016).

Paket jelajah sebagai rute untuk memperkenalkan potensi-potensi yang ada di wilayah Kotagede. Wisatawan dapat memilih paket yang ditawarkan sesuai dengan minat yang diinginkan, oleh karena itu kajian ini dimaksudkan untuk memberi kontribusi dalam analisis destinasi di salah satu tujuan penting di Kota Yogyakarta yaitu kawasan seni budaya dan heritage Kotagede dan memberikan gambaran spasial tentang salah satu atraksi wisata budaya guna memberikan pengetahuan yang informatif kepada masyarakat agar tertarik dan terus melestarikan wisata tersebut.

Partisipasi menurut (Ristiyanti, 2008) dapat diartikan sebagai keterlibatan seseorang secara sadar ke dalam interaksi sosial dalam situasi tertentu. Dengan pengertian itu, seseorang dapat berpartisipasi bila ia menemukan dirinya dengan atau dalam kelompok, melalui berbagai proses berbagi dengan orang lain dalam hal nilai, tradisi, perasaan, kesetiaan, kepatuhan dan tanggungjawab bersama. Partisipasi masyarakat menurut (Handayani, \& Priyono, 2016) adalah keikutsertaan masyarakat dalam proses pengidentifikasian masalah dan potensi yang ada di masyarakat, pemilihan dan pengambilan keputusan tentang alternatif solusi untuk menangani masalah, pelaksanaan upaya mengatasi masalah, dan keterlibatan masyarakat dalam proses mengevaluasi perubahan yang terjadi. Mikkelsen (1999) membagi partisipasi menjadi 6 (enam) pengertian, yaitu (1). Partisipasi adalah kontribusi sukarela dari masyarakat kepada proyek tanpa ikut serta dalam pengambilan keputusan. (2). Partisipasi adalah pemekaan (membuat peka) pihak masyarakat untuk meningkatkan kemauan menerima dan kemampuan untuk menanggapi proyekproyek pembangunan. (3). Partisipasi adalah keterlibatan sukarela oleh masyarakat dalam perubahan yang ditentukannya sendiri. (4). Partisipasi adalah suatu proses yang aktif, yang mengandung arti bahwa orang atau kelompok yang terkait, mengambil inisiatif dan menggunakan kebebasannya untuk melakukan hal itu. (5). Partisipasi adalah pemantapan dialog antara masyarakat setempat dengan para staf yang melakukan persiapan, pelaksanaan, monitoring proyek, agar memperoleh informasi mengenai konteks lokal, dan dampak-dampak sosial. (6). Partisipasi adalah keterlibatan masyarakat dalam pembangunan diri, kehidupan, dan lingkungan mereka.

Pentingnya partisipasi dikemukakan oleh Smylie et al, (1996), yaitu (1). Partisipasi masyarakat merupakan suatu alat guna memperoleh informasi mengenai kondisi, kebutuhan, dan sikap masyarakat setempat, yang tanpa kehadirannya program pembangunan serta proyek-proyek akan gagal. (2). Masyarakat akan lebih mempercayai proyek atau program pembangunan jika merasa dilibatkan dalam proses persiapan dan perencanaannya, karena mereka akan lebih mengetahui seluk-beluk proyek tersebut dan akan mempunyai rasa memiliki terhadap proyek tersebut. (3). Merupakan suatu hak demokrasi apabila masyarakat dilibatkan dalam pembangunan masyarakat mereka sendiri.

Suksesnya suatu program dalam hal ini program pengembangan peninggalan budaya, 
Wenang Anurogo, Muhammad Zainuddin Lubis, Hartono, Daniel Sutopo Pamungkas, Ahmad Prasetya Dilaga -- Ketahanan Kawasan Wisata Berbasis Masyarakat dalam Penguatan Ekonomi Lokal dan Pelestarian

Sumberdaya Kebudayaan Kawasan Kotagede Yogyakarta

tergantung dari partisipasi masyarakat untuk mensukseskan program tersebut, sehingga dalam posisi ini peran aktif masyarakat sangat penting artinya bagi kelancaran dan keberhasilan program tersebut dan tercapainya tujuan yang berkelanjutan. Program heritage trail dicanangkan dalam rangka usaha pemerintah dan masyarakat untuk meningkatkan pendapatan daerah. Baiquni (1998) menjelaskan bahwa pergeseran paradigma pembangunan dari pertumbuhan menuju pembangunan berkelanjutan diwarnai dinamika dan kecenderungan pembangunan saat ini, sementara itu kesadaran di kalangan masyarakat terus meningkat turut menentukan arah dan kontrol pada pembangunan.

Pemerintah berkeinginan untuk membuat perubahan dari suatu kondisi tertentu ke keadaan lain yang lebih bernilai. Agar proses perubahan itu dapat menjangkau sasaransasaran perubahan keadaan yang lebih baik dan dapat digunakan sebagai pengendali masa depan, di dalam melaksanakan pembangunan itu perlu sekali memperhatikan dari segi manusianya, karena dalam arti proses, pembangunan itu menyangkut makna bahwa manusia itu obyek pembangunan dan sekaligus subyek pembangunan. Sebagai subyek pembangunan manusia harus diperhitungkan, sebab manusia ketika menjadi subjek pembangunan memiliki nilai dan potensi yang luar biasa. Oleh karena itu, di dalam pembangunan perlu sekali mengajak subyek pembangunan tersebut untuk ikut berpartisipasi aktif dalam proses pembangunan secara berkelanjutan.

Kaitannya dengan peran serta masyarakat dalam program tertentu, peran tokoh masyarakat baik formal maupun non-formal sangat penting terutama dalam mempengaruhi, memberi contoh, dan menggerakkan keterlibatan seluruh warga masyarakat di lingkungannya guna mendukung keberhasilan program. Apalagi di masyarakat pedesaan, peran tersebut menjadi faktor determinan karena kedudukan para tokoh masyarakat masih sangat kuat pengaruhnya, bahkan sering menjadi tokoh panutan dalam segala kegiatan hidup sehari-hari warga masyarakat. Selain tokoh adat, kebudayaan yang ada dinyatakan sebagai segala sesuatu yang berhubungan erat dengan perilaku manusia dan kepercayaan, maka ia meliputi berbagai hal dalam kehidupan manusia, yang di antaranya adalah agama, pendidikan, struktur sosial ekonomi, pola kekeluargaan, kebiasaan.

Kondisi kehidupan seseorang dengan demikian dapat dikatakan bahwa sehariharinya sangat mempengaruhi setiap peristiwa sosial, dimana dalam setiap kegiatan sosial tersebut selalu melibatkan hubungan antarsubjek dan terbentuknya makna. Makna tersebut akan menentukan kesanggupan seseorang untuk terlibat dan berpartisipasi pada kegiatan tertentu dalam masyarakatnya. Tingkah laku selalu didasarkan pada makna sebagai hasil kehidupan para pelakunya. Apa yang dilakukan, dan mengapa seseorang melakukan berbagai hal, selalu didasarkan pada batasan-batasan menurut pendapatnya sendiri, dan dipengaruhi oleh latar belakang budayanya yang khusus. Budaya yang berbeda merupakan daya tarik setiap kawasan pasti memiliki perbedaan, karena kebudayaan merupakan cara khusus yang membentuk pikiran dan pandangan manusia.

Kajian objek wisata heritage trail di Kotagede ini menggunakan metode kualitatif. Qualitative research yakni penelitian yang menghasilkan temuan-temuan yang tidak cukup hanya didapat dengan menggunakan prosedur-prosedur statistik atau dengan cara- 
cara lain dari kuantifikasi atau pengukuran, tetapi dengan menunjukkan pada penelitian tentang kehidupan masyarakat, sejarah, tingkah laku, fungsionalisasi organisasi, pergerakan-pergerakan sosial, atau hubungan kekerabatan (Strauss \& Corbin, 1990). Suatu penelitian kualitatif dieksplorasi dan diperdalam dari suatu fenomena sosial atau suatu lingkungan sosial yang terdiri atas pelaku, kejadian, tempat dan waktu. Penelitian kualitatif dilakukan karena peneliti ingin mengeksplore fenomena-fenomena yang tidak dapat dikuantifikasikan yang bersifat deskriptif seperti proses suatu langkah kerja, formula suatu resep, pengertian-pengertian suatu konsep yang beragam, karakteristik suatu barang dan jasa, gambar-gambar, gaya, tata cara suatu budaya, dan sebagainya. Metode penelitian kualitatif ini lebih menfokuskan dalam pencarian data informasi dari informan langsung. Kajian ini menggunakan alat bantu data resolusi tinggi. Data resolusi tinggi ini digunakan untuk melihat lokasi rute dari jelajah kawasan. Data resolusi tinggi ini dapat berupa foto udara maupun citra penginderaan jauh yang mana dapat menghasilkan gambaran tentang objek yang dikaji dengan jelas (Anurogo et al, 2017).

Penelitian ini menggunakan metode kualitatif dengan mengacu pada beberapa alasan yang dikemukakan oleh Margono (2000: 37), yaitu (1). Untuk menanggulangi banyaknya informasi yang hilang, seperti yang dialami oleh penelitian kualitatif

Gambar 1

Kerangka Penelitian

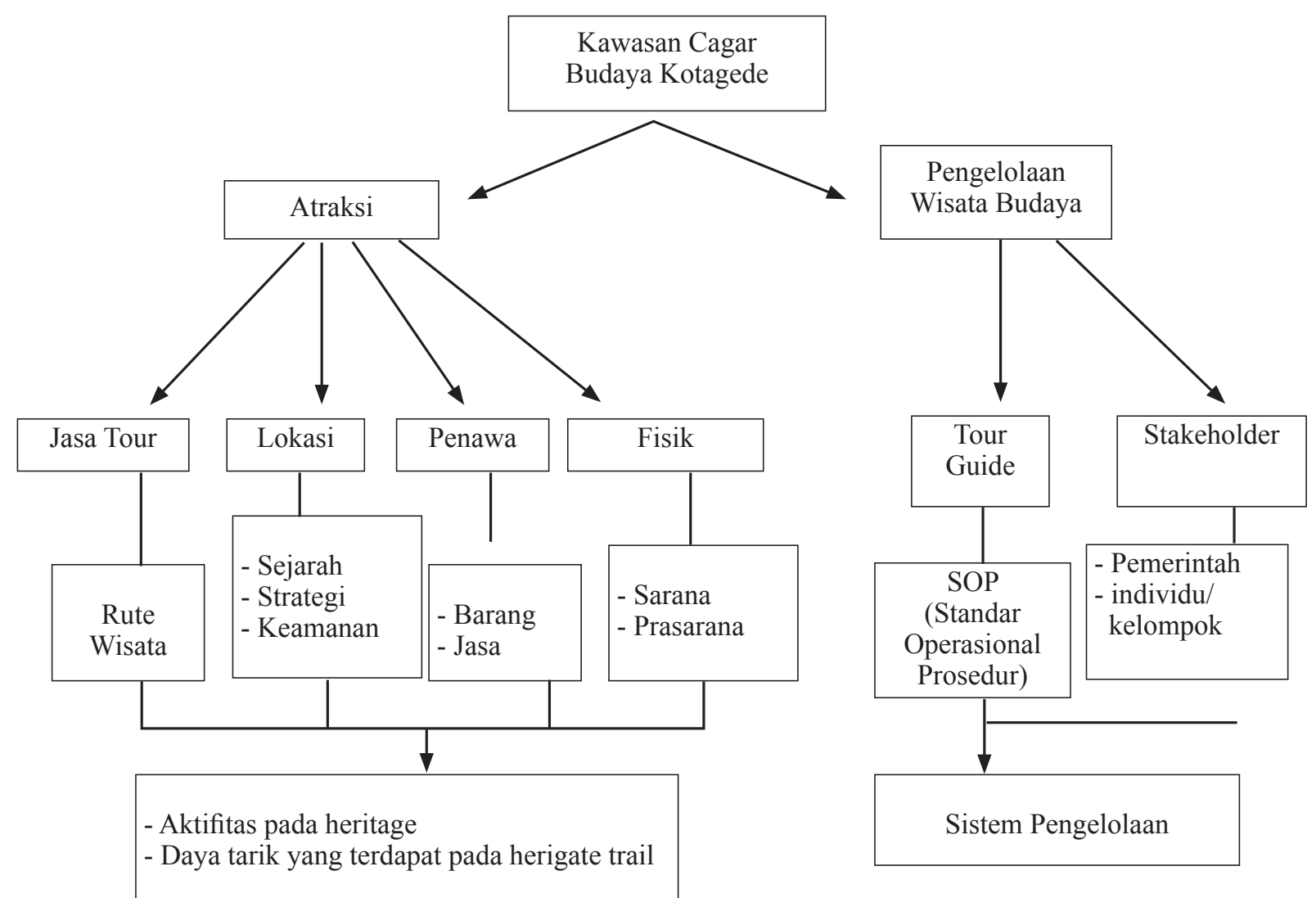

(Sumber: Analisis Data, 2017) 
Wenang Anurogo, Muhammad Zainuddin Lubis, Hartono, Daniel Sutopo Pamungkas, Ahmad Prasetya Dilaga -- Ketahanan Kawasan Wisata Berbasis Masyarakat dalam Penguatan Ekonomi Lokal dan Pelestarian

Sumberdaya Kebudayaan Kawasan Kotagede Yogyakarta

sehingga intisari konsep yang ada pada data dapat diungkap. (2). Untuk menanggulangi kecenderungan menggali data empiris dengan tujuan membuktikan kebenaran hipotesis akibat dari adanya hipotesis yang disusun sebelumnya berdasarkan berfikir deduktif seperti dalam pemikiran kuantitatif. (3). Untuk menanggulangi kecenderungan pembatasan variabel yang sebelumnya, seperti dalam penelitian kuantitatif padahal permasalahan dan variabel dalam masalah sosial sangat kompleks. (4). Untuk menanggulangi adanya indeks-indeks kasar seperti dalam penelitian kuantitatif yang menggunakan pengukuran enumerasi (perhitungan) empiris, padahal inti sebenarnya berada pada konsep-konsep yang timbul dari data.

Kerangka penelitian dalam penelitian ini ditunjukkan dalam gambar 1 .

Kajian wisata kawasan Kotagede ini menggunakan data resolusi tinggi dari citra Quickbird untuk menyajikan informasi spasial tentang jalur lokasi heritage trail di Kotagede. Kotagede sendiri secara geografis terletak di antara Koordinat X: 433540 Y: 9137551 sampai dengan Koordinat X: 434541 Y:9133978 pada Proyeksi Universal Transverse Mercator Datum WGS 1984 Zona 49 selatan garis equator. Kecamatan Kotegede merupakan salah satu dari 14 kecamatan yang ada di Kota Yogyakarta. Kecamatan Kotagede terletak di bagian Tenggara Kota Yogyakarta. Kecamatan Kotegede terletak pada $7^{\circ}-8^{\circ}$ Lintang Selatan dan $11^{\circ}-11,1^{\circ}$ Bujur Timur. Secara administratif Kecamatan Kotagede memiliki batas - batas sebagai berikut: (1). Sebelah Utara adalah Kecamatan Banguntapan, Kabupaten Bantul. (2). Sebelah Timur adalah Kecamatan Banguntapan, Kabupaten Bantul. (3). Sebelah Selatan adalah Kecamatan Banguntapan, Kabupaten
Bantul. (\$). Sebelah Barat adalah Kecamatan Umbulharjo.

Kecamatan Kotagede memiliki luas wilayah 307 hektar. Kelurahan terluas adalah Kelurahan Rejowinangun dengan luas wilayah 125 hektar dan kelurahan terkecil adalah Kelurahan Purbayan dengan luas wilayah 83 hektar (tabel 1).

Tabel 1

Luas Kecamatan Kotagede per Kelurahan

\begin{tabular}{|c|c|c|c|}
\hline No & Kelurahan & Luas (Ha) & Persentase $(\%)$ \\
\hline 1 & Prenggan & 99 & 32,25 \\
\hline 2 & Purbayan & 83 & 27,03 \\
\hline 3 & Rejowinangun & 125 & 40,72 \\
\hline Jum & lah & 307 & 100 \\
\hline
\end{tabular}

(Sumber, Badan Pusat Statistik Yogyakarta, 2014)

Kecamatan Kotegede secara garis besar wilayah dataran rendah yang dilintasi oleh Sungai Gajahwong. Kecamatan Kotagede berada pada ketinggian 113 mdpl. Jenis tanah Kecamatan Kotagede sebagian besar adalah tanah regosol dan kambiasol yang lepas - lepas (porus). Kecamatan Kotagede yang bertopografi datar membuat aktivitas masyarakat cukup bervariasi seperti pertanian, perdagangan jasa dan lain sebagainya.

Kecamatan Kotagede memiliki kepadatan penduduk 10.429 jiwa $/ \mathrm{km} 2$. Kepadatan penduduk tertinggi berada di Kelurahan Prenggan yakni 13.020 jiwa/km2 sedangkan kepadatan penduduk terendah berada di Kelurahan Rejowinangun yakni 9.339 jiwa/ $\mathrm{km} 2$. Rasio jenis kelamin Kecamatan Kotagede sebesar 97,14 persen yang berarti jumlah 
Tabel 2

Jumlah Penduduk, Kepadatan Penduduk, dan Sex Ratio Kecamatan Kotagede

\begin{tabular}{|c|c|c|c|c|c|c|}
\hline No & Kelurahan & Laki - Laki (Jiwa) & Perempuan (Jiwa) & Jumlah (Jiwa) & $\begin{array}{c}\text { Kepadatan (Jiwa/ } \\
\text { km2) }\end{array}$ & Sex Ratio (\%) \\
\hline 1 & Prenggan & 5.277 & 5.530 & 10.807 & 13.020 & 95,42 \\
\hline 2 & Purbayan & 4.658 & 4.878 & 9.536 & 9.632 & 95,49 \\
\hline 3 & Rejowinangun & 5.841 & 5.833 & 11.674 & 9.339 & 100,14 \\
\hline \multicolumn{2}{|c|}{ Jumlah } & 15.776 & 16.241 & 32.017 & 10.429 & 97,14 \\
\hline
\end{tabular}

(Sumber: Badan Pusat Statistik Kota Yogyakarta, 2014)

penduduk laki - laki di Kecamatan Kotagede ialah 97,14 persen dari penduduk perempuan. Kelurahan Rejowinangun memiliki rasio jenis kelamin yang berimbang dengan nilai sebesar 100,14 persen sedangkan Kelurahan Prenggan dan Purbayan memiliki jumlah penduduk perempuan lebih banyak dibandingkan penduduk laki - laki (tabel 2).

Sarana perdagangan yang terdapat di Kecamatan Kotagede antara lain pasar, warung, toko, minimarket dan supermarket. Sarana perdagangan yang paling banyak terdapat di Kecamatan Kotagede adalah toko sejumlah 501 buah sedangkan yang terendah adalah supermarket yang hanya berjumlah 1 buah berada di Kelurahan Prenggan. Persebaran keberadaan toko di Kecamatan Kotagede dapat dikatakan merata pada setiap kelurahannya. Kelurahan yang memiliki toko terbanyak terdapat di Kelurahan Purbayan sejumlah 177 buah kemudian diikuti Kelurahan Rejowinangun sejumlah 166 buah dan terendah terdapat di Kelurahan Prenggan sejumlah 158 buah. Sarana perdagangan terbanyak kedua di Kecamatan Kotagede ialah warung sebanyak 382 buah. Keberadaan warung terbanyak terdapat di Kelurahan Prenggan sebanyak 229 buah dan terendah terdapat di Kelurahan Rejowinangun sebanyak 72 buah. Terdapat ketimpangan yang signifikan dalam distribusi warung di Kecamatan Kotagede yang terpusat di Kelurahan Prenggan. Hal tersebut dikarenakan Kelurahan Prenggan merupakan pusat dari Kecamatan Kotagede.

Struktur ekonomi suatu wilayah dapat dilihat dari data PDRB. Dari data tersebut dapat dilihat sektor mana yang berperan besar terhadap perekonomian suatu daerah. Data PDRB Kecamatan Kotagede tahun 2013 baik harga berlaku maupun konstan menunjukkan bahwa sektor jasa - jasa merupakan sektor yang paling dominan terhadap perekonomian Kecamatan Kotagede. Sektor jasa di Kecamatan Kotagede memiliki nilai PDRB sebesar 203.287,85 jutaan rupiah menurut harga berlaku dan $71.109,78$ jutaan rupiah menurut harga konstan. Sektor dengan kontribusi terendah terhadap perekonomian di Kecamatan Kotagede ialah sektor pertambangan dan galian dengan tidak ada kontribusi sama sekali. Hal tersebut dikarenakan Kecamatan Kotagede merupakan salah satu kecamatan yang dilindungi bentuk bangunannya oleh pemerintah Daerah Istimewa Yogyakarta karena memiliki banyak bangunan cagar budaya. Sektor yang memiliki kontribusi terbesar kedua terhadap perekonomian Kecamatan Kotagede ialah sektor perdagangan, hotel dan restoran. Hal tersebut dikarenakan di Kecamatan Kotagede terdapat salah satu pasar tertua di Provinsi DIY serta sebagai pusat industri perak di Provinsi DIY. Selain itu Kecamatan Kotagede juga memiliki daya tarik wisata dari cagar 
Wenang Anurogo, Muhammad Zainuddin Lubis, Hartono, Daniel Sutopo Pamungkas, Ahmad Prasetya Dilaga -- Ketahanan Kawasan Wisata Berbasis Masyarakat dalam Penguatan Ekonomi Lokal dan Pelestarian Sumberdaya Kebudayaan Kawasan Kotagede Yogyakarta

Tabel 3

Jumlah Tempat Rekreasi, Wisatawan dan Hotel di Kecamatan Kotagede

\begin{tabular}{llllll}
\hline \multirow{2}{*}{ No } & Kelurahan & Tempat & Wisatawan & Hotel \\
\cline { 3 - 6 } & Rekreasi & Asing & Domestik & \\
\hline 1 & Prenggan & 0 & 0 & 0 & 0 \\
\hline 2 & Purbayan & 0 & 0 & 0 & 0 \\
\hline 3 & Rejowinangun & 1 & 15.475 & 1.532 .041 & 7 \\
\hline Jumlah & 1 & 15.475 & 1.532 .041 & 7 \\
\hline
\end{tabular}

(Sumber : Badan Pusat Statistik Kota Yogyakarta, 2014

Gambar 2

Lokasi Kajian Wisata Kotagede

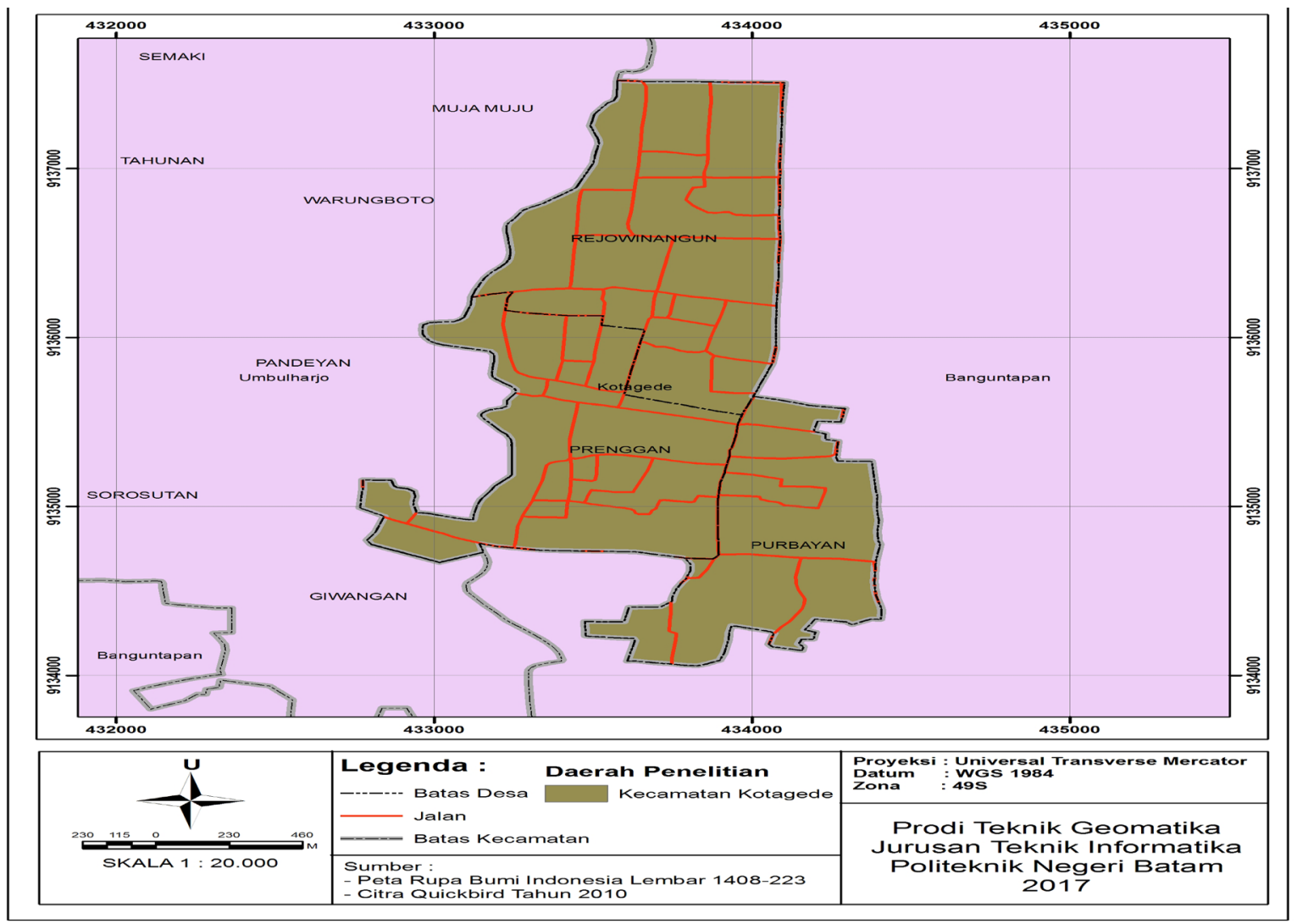

(Sumber: Lokasi Kajian wisata heritage trail Kotagede (Analisis Data, 2017)

budaya yang dimilikinya sehingga sektor ini memiliki potensi untuk dikembangkan terlebih pada sektor pariwisata. Faktor utama dalam pengembangan sektor pariwisata adalah ketersediaan sarana dan prasarana pariwisata. Ketersediaan sarana dan prasarana pariwisata yang baik akan mendukung daya tarik objek wisata yang dimiliki oleh suatu daerah. Kecamatan Kotagede memiliki 1 tempat rekreasi yaitu Kebun Binatang Gembira Loka yang terdapat di Kelurahan Rejowinangun. Keberadaan Kebun Binatang Gembira Loka tersebut mampu menarik wisatawan asing sebanyak 15.475 orang dan wisatawan 
domestik 1.532.041 orang pada tahun 2013. Kecamatan Kotagede memiliki hotel sejumlah 7 buah yang kesemuanya terdapat di Kelurahan Rejowinangun. Dari tabel 3 terlihat bahwa konsentrasi pengembangan pariwisata terpusat di Kelurahan Rejowinangun.

Lokasi wisata di Kotagede ditunjukkan dalam gambar 2.

\section{PEMBAHASAN}

Hasil penelitian yang diperoleh adalah atraksi-atraksi wisata yang terdapat di kawasan Cagar Budaya Kotagede yang berisi lokasi wisata serta daya tarik yang dimiliki. Proses pengambilan data menggunakan studi literatur, wawancara, dan observasi. Observasi dilakukan untuk mengamati keadaan lokasi wisata sehingga dapat diketahui permasalahanpermasalahan yang ada. Permasalahan yang harus dibenahi yaitu, kurangnya informasi mengenai kegiatan jelajah pusaka yang dikelola oleh organisasi pemuda khususnya Desa Prenggan, terbatasnya promosi daya tarik kawasan Kotagede selain sentral kerajianan perak, dan minimnya kerjasama antara biro perjalanan, dinas terkait, dengan pengelola.

Cagar Budaya Kotagede yang menjadi daya tarik wisata dapat dijelaskan sebagai berikut.

Pertama, peninggalan fisik. Benda benda yang mendukung kawasan wisata Kotagede merupakan benda yang digunakan sampai dengan saat ini dan dimanfaatkan untuk kepentingan pariwisata. Benda-benda budaya di kawasan ini terdiri dari peninggalan fisik dan peninggalan non fisik. Peninggalan fisik terbagi menjadi dua yaitu benda bergerak dan benda tidak bergerak. Benda-benda tidak bergerak sebagian besar berupa bangunan berciri tradisional, dan bangunan yang sudah mendapat berbagai pengaruh Barat. Sedangkan benda bergerak merupakan peninggalan atau prasasti yang memungkinkan untuk dapat dipindahkan tanpa merubah fungsi, bentuk dan sejarahnya. Peninggalan non fisik merupakan nilai budaya berupa kerajinan, kuliner, dan kesenian.

Kedua, benda-benda bergerak. Bendabenda bergerak tersebut berjumlah 9 (sembilan) buah, sebagai berikut.

(1). Watu Gilang, terletak di Dusun Dalem, Kelurahan Purbayan, terbuat dari batu andesit, ukuran panjang $141 \mathrm{~cm}$, lebar $119 \mathrm{~cm}$, tinggi $12 \mathrm{~cm}$. Dahulu Watu Gilang ini merupakan tempat duduk Panembahan Senopati, dan menjadi hak milik dari Kraton Yogyakarta yang tersimpan dan kondisinya masih utuh terawat hingga sekarang. Daya tarik dari benda ini adalah adanya prasasti berhuruf cetak, berbahasa Latin, Perancis, Belanda, dan Italia. Salah satu tulisan yang ada di prasati tersebut adalah "Ad Aeternam Mempriam Sortis Infelicis" yang berarti "untuk memperingati nasib yang tidak baik."

(2). Watu Gatheng, terletak di Dusun Dalem, Kelurahan Purbayan, dari batu kalsit kuning, berjumlah 3 buah dengan diameter $35 \mathrm{~cm}, 30 \mathrm{~cm}$, dan $16 \mathrm{~cm}$. Konon sebagai alat main gatheng Raden Rangga, putra Panembahan Senopati.

(3). Yoni, terletak di Dusun Dalem, Kelurahan Purbayan, terbuat dari batu andesit, ukuran panjang $82 \mathrm{~cm}$, lebar $82 \mathrm{~cm}$, tinggi 29 $\mathrm{cm}$. Konon sebagai tempat Watu Gatheng yang dulunya berjumlah 5 buah. Yoni juga terdapat di Sendang Selirang, kompleks Masjid Makam Kotagede, Jagalan, Banguntapan, Bantul. Yoni tersebut terbuat dari batu andesit dengan panjang $49 \mathrm{~cm}$, lebar $49 \mathrm{~cm}$, dan tinggi $33 \mathrm{~cm}$, yang saat ini dipakai untuk tempat meletakkan sesaji.

(4). Watu Gentong, terletak di Dusun Dalem, Kelurahan Purbayan, terbuat dari batu 
Wenang Anurogo, Muhammad Zainuddin Lubis, Hartono, Daniel Sutopo Pamungkas, Ahmad Prasetya Dilaga -- Ketahanan Kawasan Wisata Berbasis Masyarakat dalam Penguatan Ekonomi Lokal dan Pelestarian

Sumberdaya Kebudayaan Kawasan Kotagede Yogyakarta

andesit. Ukuran diameter bibir $65 \mathrm{~cm}$, tebal bibir: $3 \mathrm{~cm}$, tinggi $65 \mathrm{~cm}$, kedalaman lubang: $46 \mathrm{~cm}$, dan merupakan tempat berwudhu/ bersuci.

(5). Arca Garuda (Manuk Beri), terletak di Dusun Gedongkuning, Kelurahan Rejowinangun. Terbuat dari batu andesit dilapisi semen, ukuran tinggi $160 \mathrm{~cm}$, lebar $175 \mathrm{~cm}$. Dahulu Arca Garuda ini merupakan bagian dari sebuah pemandian. Kemungkinan arca ini merupakan bagian dari bangunan (pemandian) sehingga mungkin juga bukan benda cagar budaya bergerak.

(6). Arca Relief Manusia, terletak di Dusun Gedong Kuning, Kelurahan Rejowinangun, terbuat dari batu andesit dan semen bagian luar telah dilapisi semen, sehingga diragukan kekunoannya, ukuran tinggi $49 \mathrm{~cm}$, lebar $83 \mathrm{~cm}$, ditemukan saru lokasi dengan Arca Garuda.

(7). Tugu Gerbang Muja Muju, terletak di Dusun Gedong Kuning, Kelurahan Rejowinangun, terbuat dari batu bata, ukuran tinggi $165 \mathrm{~cm}$, lebar $55 \mathrm{~cm}$, dengan kondisi saat ini tidak terawat. Menurut pemiliknya KRT. Sukarjono, tugu ini pindahan dari daerah Muja Muju sehingga disebut Gerbang Muja Muju.

(8). Doorpel, terletak di depan kompleks Masjid Makam Kotagede, dengan ukuran panjang $184 \mathrm{~cm}$, lebar $46 \mathrm{~cm}$, dan tinggi 40 $\mathrm{cm}$. Dahulu Doorpel ini dipakai untuk undakan masuk ke salah satu kompleks makam.

(9). Lapik Arca, terletak di Kompleks Makam Kotagede, terbuat dari batu andesit dengan panjang $58 \mathrm{~cm}$, tinggi $21 \mathrm{~cm}$, dan lebar $56 \mathrm{~cm}$. Benda ini sekarang berfungsi sebagai tempat untuk menaruh sesaji.

Ketiga, benda-benda tidak bergerak. Benda-benda tidak bergerak tersebut berjumlah 5 (lima) buah, sebagai berikut.
(1). Tugu Peninggalan Banguntopo, terletak di Dusun Gedong Kuning, Kelurahan Rejowinangun, terbuat dari batu bata diplester semen, dan memilik ukuran tinggi $208 \mathrm{~cm}$, panjang $89 \mathrm{~cm}$, dan lebar $83 \mathrm{~cm}$. Kondisi terawat dan dipakai sebagai pagar oleh penduduk, keberadaanya dihubungkan dengan Tugu Cendana Sari.

(2). Arca Nogobondo, terletak di Dusun Nogowilangun, Kelurahan Rejowinangun. Arca pertama pecah bagian paruh, tinggi yang tampak (arca terpendam) $93 \mathrm{~cm}$, lebar yang menjulur dari tembok $183 \mathrm{~cm}$. Arca kedua pecah bagian kepala, belum ada yang mengukur karena berada di lereng sungai. Kondisi keseluruhan tidak terawatt dan besar kemungkinan arca ini juga bagian dari suatu bangunan, mungkin bekas saluran air dari sebuah pemandian yang ditunjukkan adanya semacam saluran air yang keluar melalui mulut naga.

(3). Kompleks Makam Hastha Renggo. Secara administratif Kompleks Makam Hastha Renggo ini berada di Dusun Dalem, Kelurahan Purbayan, Kecamatan Kotagede. Menurut juru kunci KRT. Hartono, kompleks makam ini merupakan makam putra raja Mataram beserta keluarganya. Tokoh yang dimakamkan di sini adalah Gusti Haryo Juminah (calon raja Mataram ke VIII ) tetapi gagal karena terkena hasutan Belanda. Tokoh lain adalah putra HB VII dan istrinya. Keunikan kedua makam ini ada pada hiasannya yang terbuat dari kelereng. Makam ini dibangun 29 Desember 1934 dengan candra sengkala pada gerbang berbunyi "Rampungipun ing dinten Jemuwah Legi 1934.

(4). Masjid Mataram. Masjid Mataram berada sekitar 200 meter di Barat Daya Pasar Kotagede. Bangunan masjid ini merupakan salah satu bangunan tertua non candi yang 
ada di wilayah Yogyakarta. Bahwa masjid ini merupakan masjid kerajaan, ditandai dengan mustaka atau mahkota yang berciri khas masjid keprabon. Mustaka Masjid Mataram terbuat dari tembaga, dan bagian dasar mustaka dikelilingi bentuk stilisasi daundaunan maupun bunga-bungaan, di atasnya ada penunjuk kiblat, dan paling atas adalah tongkat gada bulat membesar di atas. Pada masa lalu mustaka masjid Jawa, begitu juga dengan Masjid Mataram, mengambil contoh mustaka Masjid Agung Demak sebagai masjid kerajaaan Islam pertama di Jawa. Masjid Mataram berdiri dalam satu kompleks dengan Pasareyan Agung Kotagede, dan dikelilingi oleh tembok setinggi sekitar 2,5 meter. Ada dua pintu gerbang untuk memasuki Kompleks Masjid Mataram ini, yakni gerbang utama untuk jamaah di sisi Timur dan gerbang pelayanan untuk kaum kudus di sisi Utara. Atap utama Masjid Mataram adalah tajug tumpang dua, didukung oleh empat tiang utama saka guru dari kayu. Di dalam ruang utama terdapat sebuah mimbar yang berasal dari pemberian Sultan Palembang, anak keturunan Prabu Brawijaya V. Sedangkan kenthongan dan bedhug Kyai Dhondhong diletakkan di serambi Masjid Mataram. Di balik Masjid Mataram dimakamkan para leluhur Kerajaan Mataram. Dengan demikian, area ini memiliki nilai religius sekaligus spiritual sangat tinggi bagi Keraton Mataram. Masjid ini juga bisa menjadi bukti masuknya Islam ke masyarakat tradisional di pedalaman Jawa, yang pada waktu itu masih didominasi oleh kepercayaan asli dan Hindu. Kepercayaan asli muncul dalam penataan masjid yang menyatu dengan makam para tokoh, dan karakter Hindu terlihat pada langgam rancangan pagar keliling dan gapura paduraksa. Unsur air yang mengelilingi tempat ibadah juga merupakan kelanjutan dari unsur Hindu. Pada masa Ki Ageng Pemanahan, Masjid Mataram ini awalnya masih berupa langgar. Oleh panembahan Senopati, bangunan langgar ini kemudian dipindahkan menjadi cungkup makam. Sedangkan di tempat tersebut didirikan bangunan masjid induk. Peristiwa ini terjadi pada tahun 1587, sebagaimana tertera pada kelir gapura masjid. Tahun 1587 adalah tahun keruntuhan Kerajaan Pajang dan pendirian Kerajaan Mataram. Dengan demikian, pendirian Masjid Mataram tersebut menandai saat penobatan Senopati menjadi raja di Keraton Mataram kemudian ditambahkan bangunan berupa serambi. Unsur kekunoan Masjid Mataram yang menjadi daya tarik tambahan wisata bagi wisatawan adalah (a). Mimbar, terbuat dari kayu berukir, ukuran panjang $220 \mathrm{~cm}$, lebar $105 \mathrm{~cm}$, dan tinggi 260 cm. (b). Bedug kono berasal dari Kayu Bayam dari Kulon Progo, memiliki panjang 180 cm dengan diameter $102 \mathrm{~cm}$. (c). Alqur'an. Alqur'an ini hanya memuat surat-surat tertentu saja, di dalamnya tertulis Kanjeng Raden Adipati Sosrodiningrat Kaping 3. Ukuran panjang $33 \mathrm{~cm}$, lebar $21 \mathrm{~cm}$, tebal 2 $\mathrm{cm}$, serta berjumlah 10 dan hingga sekarang masih dipakai. (d). Rekal, yaitu tempat untuk membaca Al-qur'an terbuat dari kayu, berjumlah dua buah. Rekal yang berukuran besar memiliki panjang $41,5 \mathrm{~cm}$, lebar $17 \mathrm{~cm}$ , tebal 1,2 cm. Rekal berukuran kecil memiliki panjang 17,5 cm, lebar $13 \mathrm{~cm}$, tebal $1,5 \mathrm{~cm}$.

(5). Rumah- Rumah Tradisional. Ini dapat dikelompokkan ke dalam 5 (lima) buah, sebagai berikut.

(a). Dalem Proyodanan. Rumah Tradisional Proyodanan merupakan rumah peninggalan Alm. Proyodrono, dibangun tahun 1912. Rumah ini sekarang dimiliki 
Wenang Anurogo, Muhammad Zainuddin Lubis, Hartono, Daniel Sutopo Pamungkas, Ahmad Prasetya Dilaga -- Ketahanan Kawasan Wisata Berbasis Masyarakat dalam Penguatan Ekonomi Lokal dan Pelestarian

Sumberdaya Kebudayaan Kawasan Kotagede Yogyakarta

oleh HM. Muslim Anwarpranoto (keturunan ke-3 Proyodrono). Arsiterkurnya bergaya Eropa, dengan tiang dan bangunan yang tinggi, serta hiasan cawan-cawan keramik. Pembagian ruangnya mengikuti pola rumah tradisional, terdiri dari kuncungan, baklareta, dan pringgitan, untuk bagian depan; dalem tengah, sentong, emper belakang, untuk dalem tengah atau inti; dan godri atau dapur, kamar mandi/ WC; Gandok kiwo dan tengen, untuk rumah samping; gudang, sumur, dan ruangan lain, untuk ruang pelengkap. Atap bentuk limasan, lantai tegel berwarna kuning dan sebagian dihiasi motif kertas tempel. Fungsi rumah sekarang mengarah ke fungsi sosial, komersial, tempat pertemuan, rapat, resepsi pernikahan dan sebagainya. Bagian gandok kiwo dan tengen untuk guest house. Secara umum rumah ini tidak banyak mengalami perubahan. Dalem Proyodanan berada sekitar 750 meter di Barat Laut Pasar Kotagede, persisnya di Jalan Mandarakan 5, Kelurahan Prenggan, Kotagede. Dalem Proyodranan adalah satu wujud rumah kalang yang berada di sisi dalam Sungai Gajahwong. Untuk menopang biaya pemeliharaan tinggi, dahulu pihak ahli waris menyewakan tempat ini untuk guest house, gedung resepsi pengantin, maupun gedung pertemuan. Namun gempa dahsyat 27 Mei 2006 telah menghentikan segalanya.

(b). Dalem Sopingen. Dalem Sopingen berada sekitar 200 meter di Barat Laut Pasar Kotagede. Dalem Sopingen adalah rumah kediaman Raden Amat Dalem Sopingi. Nama Sopingen sendiri diambil dari nama Sopingi. Bersama Raden Amat Dalem Mustahal, Raden Amat Dalam Sopingi menjabat sebagai kepala lurah juru kunci itu, Raden Amat menyiapkan rumahnya, juga berfungsi sebagai tempat singgah, berkumpul, dan beristirahat bagi pejabat kerajaan yang akan berziarah di makam raja-raja Mataram di Kotagede. Meski Pendapa Sopingen milik privat, di era 1900-1980 pendapa Sopingen pernah menjadi pusat ruang public egaliter di Kotagede. Selain bermacam denyut kesenian, gelegak politik pun pernah berlangsung di pendapa ini. Meskipun fungsinya di masa lalu cukup penting, Dalem Sopingen kini telah dijual pemiliknya. Sopingen telah kehilangan auranya, sebagai ruang publik Sopingen tidak berdaya, tidak mampu mengenang masa lalunya, tidak sempat mencatat peristiwaperistiwa heroik yang pernah dialaminya. Rumah ini merupakan tipe rumah Jawa asli, beratap joglo, dengan pembagian ruang depan terdiri dari pendapa, pringgitan, dalem ageng, gendak kiwo, gendak tengen, dan bangunan pelengkap lain, dapur dan sumur.

(c). Pasar Kotagede. Sejarawan memperkirakan lokasi Pasar Kotagade sekarang adalah sama dengan Pasar Gedhe di zaman Mataram. Pasar Kotagede adalah bagian dari konsep Catur Gatra Tunggal. Empat wahana menjadi kesatuan tunggal, terpisah tetapi terhubung oleh koridor jalanjalan. Pasar sebagai pusat perekonomian, Alunalun sebagai pusat adat budaya masyarakat, Masjid sebagai pusat peribadatan, dan Keraton sebagai pusat kekuasaan. Sutawijaya dibimbing pamannya Ki Gede Pemanahan, ketika hendak mengembangkan sebuah kota, membuka hutan Mentaok, kemudian, yang dibangun terlebih dahulu adalah sebuah pasar yang besar, sehingga pada mulanya kota itu dikenal dengan nama Pasar Gedhe, atau masyarakat luas menyebutnya, Sargedhe. Keputusan Sutawijaya untuk membuka pasar terlebih dahulu, dinilai sangat tepat, sebab pasar adalah jantung perekonomian. Pasaran legi adalah aktivitas luberan pasar di pasar 
Kotagede. Kegiatan jual beli para pedagang berada di luar bangunan pasar, di tengah jalan, di lorong-lorong kampung sekitar pasar. Aktivitas perdagangan jauh lebih besar di hari Legi ketimbang di hari lain. Pedagang dari tempat yang jauh seperti Piyungan, Imogiri, Terong, Dlingo atau Magelang banyak yang berjualan ketika hari pasaran legi saja.

d). Alun-alun. Lokasinya terletak di sebelah Selatan Pasar Kotagede dan di Timur Masjid Agung Mataram, Kampung Alunalun diduga kuat adalah bekas alun alun Mataram Islam. Tidak diketahui secara pasti kapan perubahan fungsi tersebut. Perubahan tersebut terjadi jauh setelah runtuhnya kerajaan Mataram Islam. Sekarang tidak ada tanah lapang meskipun namanya alunalun. Perkampungan padat penduduk dengan banyak rumah tradisional Jawa yang masih terpelihara baik.

(e). Babon Aniem. Babon Aniem merupakan salah satu landmark kota yang dimiliki Kotagede. Babon Aniem adalah gardu listrik yang berada di sudut Pasar Kotagede. Gardu listrik ini dibangun di awal 1990 an. Disebut Babon karena gardu listrik ini merupakan gardu induk, dalam bahasa Jawa "babon" merupakan induk betina. Sedangkan Aniem digunakan karena gardu pusat kontrol listrik tersebut merupakan warisan perusahaan listrik pemerintah Belanda, NV. ANIEM ( Algemeen Nederlands Electricitiet Maatchspij ). Ketika gempa tahun 2006 bangunan Babon Aniem roboh. PT. Total Indonesia merekonstruksi kembali bekerjasama dengan Pemkot Yogyakarta dan masyarakat pelestari pusaka Kotagede.

Gambar 3

Peta Rute Jelajah Spiritual Kecamatan Kotagede Yogyakarta

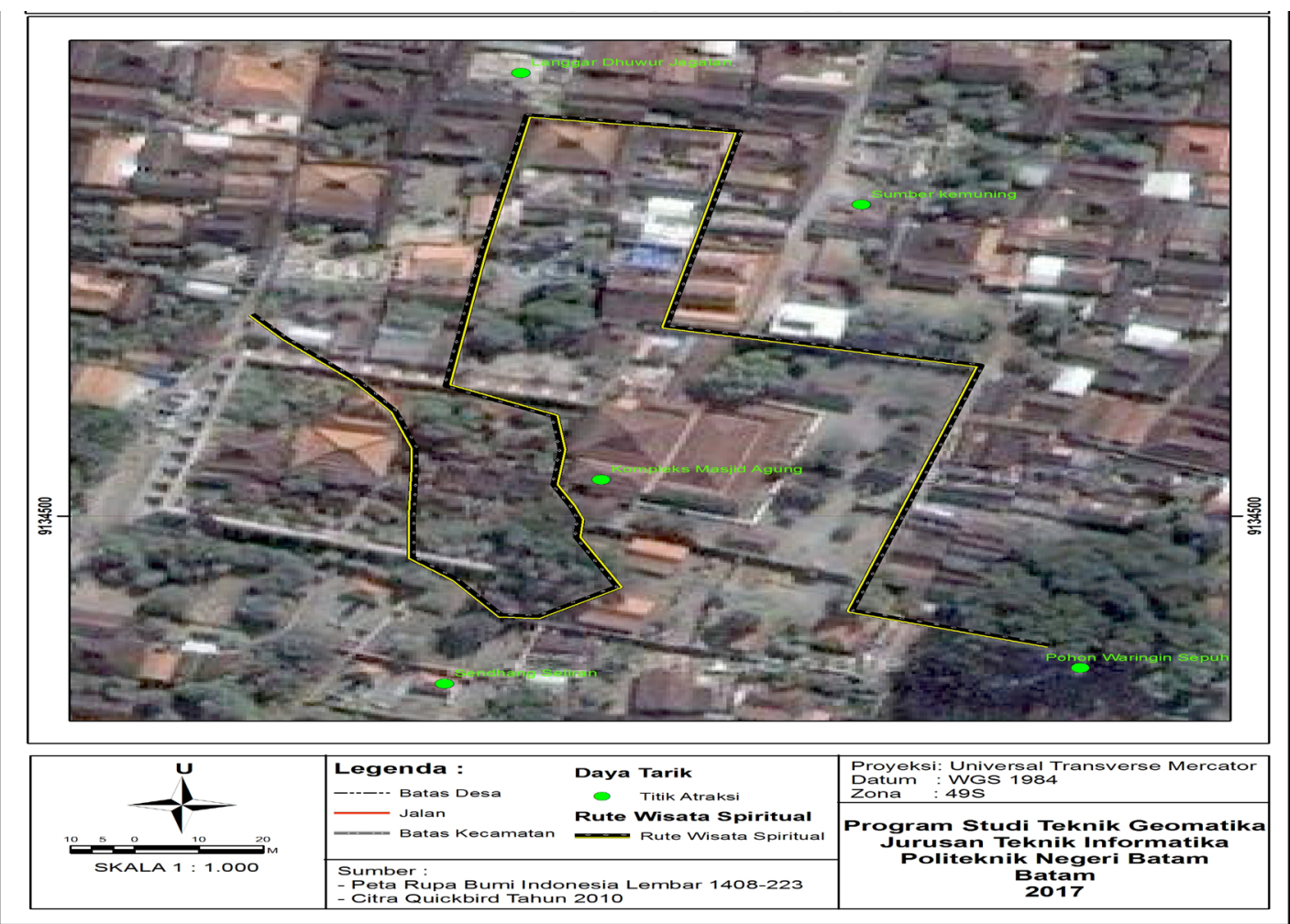

(Sumber: Analisis Data, 2017) 
Wenang Anurogo, Muhammad Zainuddin Lubis, Hartono, Daniel Sutopo Pamungkas, Ahmad Prasetya Dilaga -- Ketahanan Kawasan Wisata Berbasis Masyarakat dalam Penguatan Ekonomi Lokal dan Pelestarian Sumberdaya Kebudayaan Kawasan Kotagede Yogyakarta

Gambar 4

Peta Rute Jelajah Lorong

Kecamatan Kotagede Yogyakarta

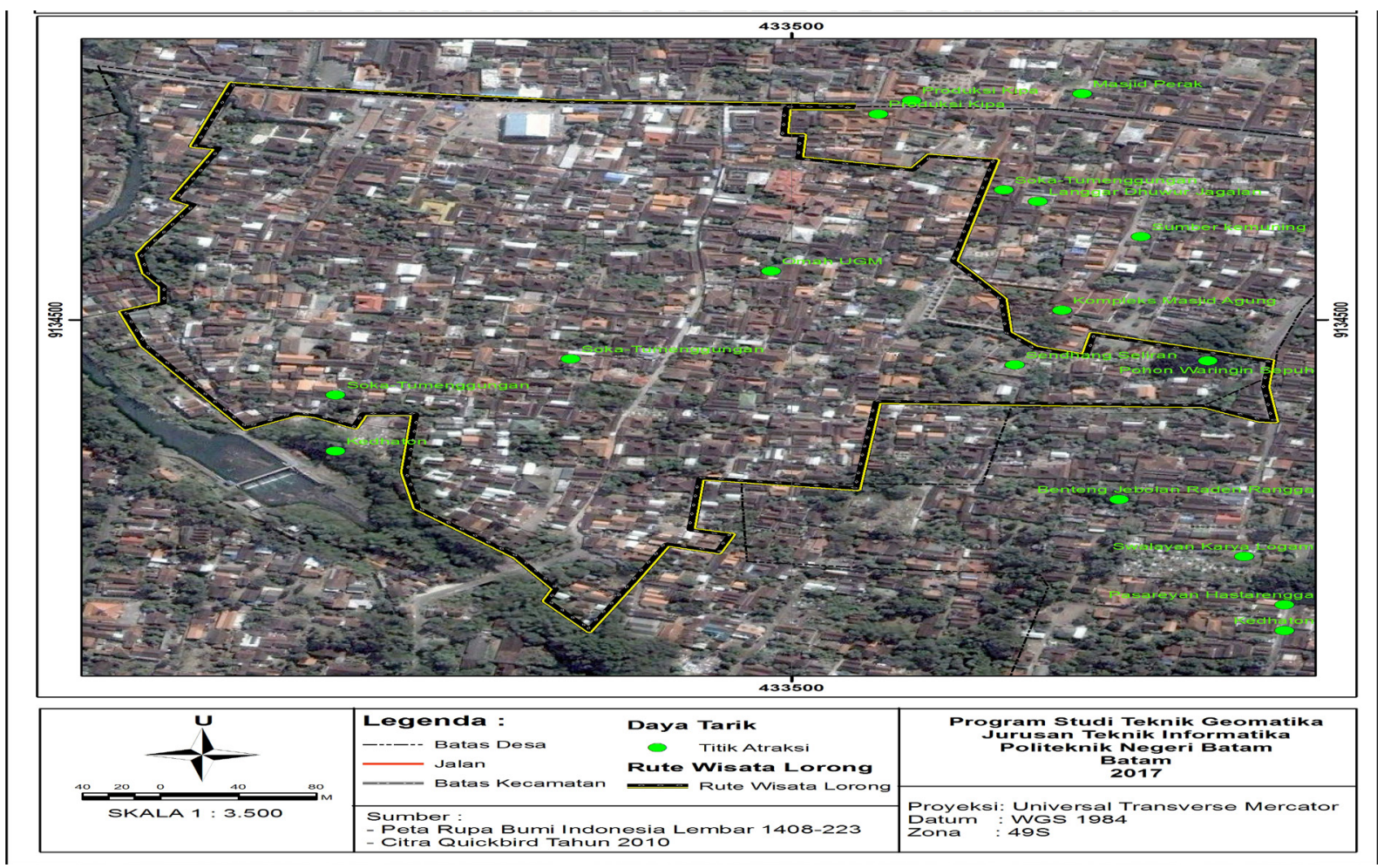

(Sumber: Analisis Data, 2017)

Daya tarik keseluruhan yang tersedia, pengelola wisata telah mengemasnya ke dalam paket wisata "Jelajah Pusaka Kotagede" (Kotagede Haritage Trail), yang terdiri dari 4 (empat) paket dengan rute yang direkomendasikan.

Pertama, paket wisata jelajah spiritual dengan lama perjalanan selama kurang lebih satu jam. Start dimulai dari Kampung Dondongan - Kompleks Masjid Agung Pasareyan Hastarengga - Sendhang Seliran - Lorong Krintenan (Pengrajin kipo) - Pohon Waringin Sepuh (gambar 3).

Kedua, paket wisata jelajah lorong dengan lama perjalanan kurang lebih 3 (tiga) jam. Perjalanan dimulai dari Kantor Kelurahan Jagalan - Kampung Njurang (pengrajin perak) - Tirta Pandan Sari (Pengrajin kipo) - Lorong Bodon - Lorong Pondongan -
Lorong Krintenan - Kompleks Masjid Agung - Kawasan Ngerikan - Gang Soka - Kantor Kelurahan Jagalan (gambar 4).

Ketiga, paket wisata jelajah arsitektural dengan estimasi waktu perjalanan selama 3 (tiga) jam. Perjalanan dimulai dari Kedhaton - Cepuri/ Benteng Dalam - Between Two Gate - Lorong Alun-alun - Kompleks Masjid Agung - Pasar Gedhe - Rumah Tradisional di Klaster Sopingen - Masjid Perak - Kawasan Ngerikan - Gang Soka - Omah UGM - Kampung Bodon - dan berakhir di Omah Kalang (gambar 5).

Keempat, paket wisata jelajah studi dengan lama perjalanan kurang lebih 4 (empat) jam. Perjalanan dimulai dari Kantor Kelurahan Jagalan - Dalem Prayadranan - Klaster Soka Tumenggungan - Omah UGM - Pos Malang - Langgar Dhuwur di Jagalan - Gang Soka Sumber Kemuning - Kompleks Masjid Agung 
Gambar 5

Peta Rute Jelajah Arsitektural Kecamatan Kotagede Yogyakarta

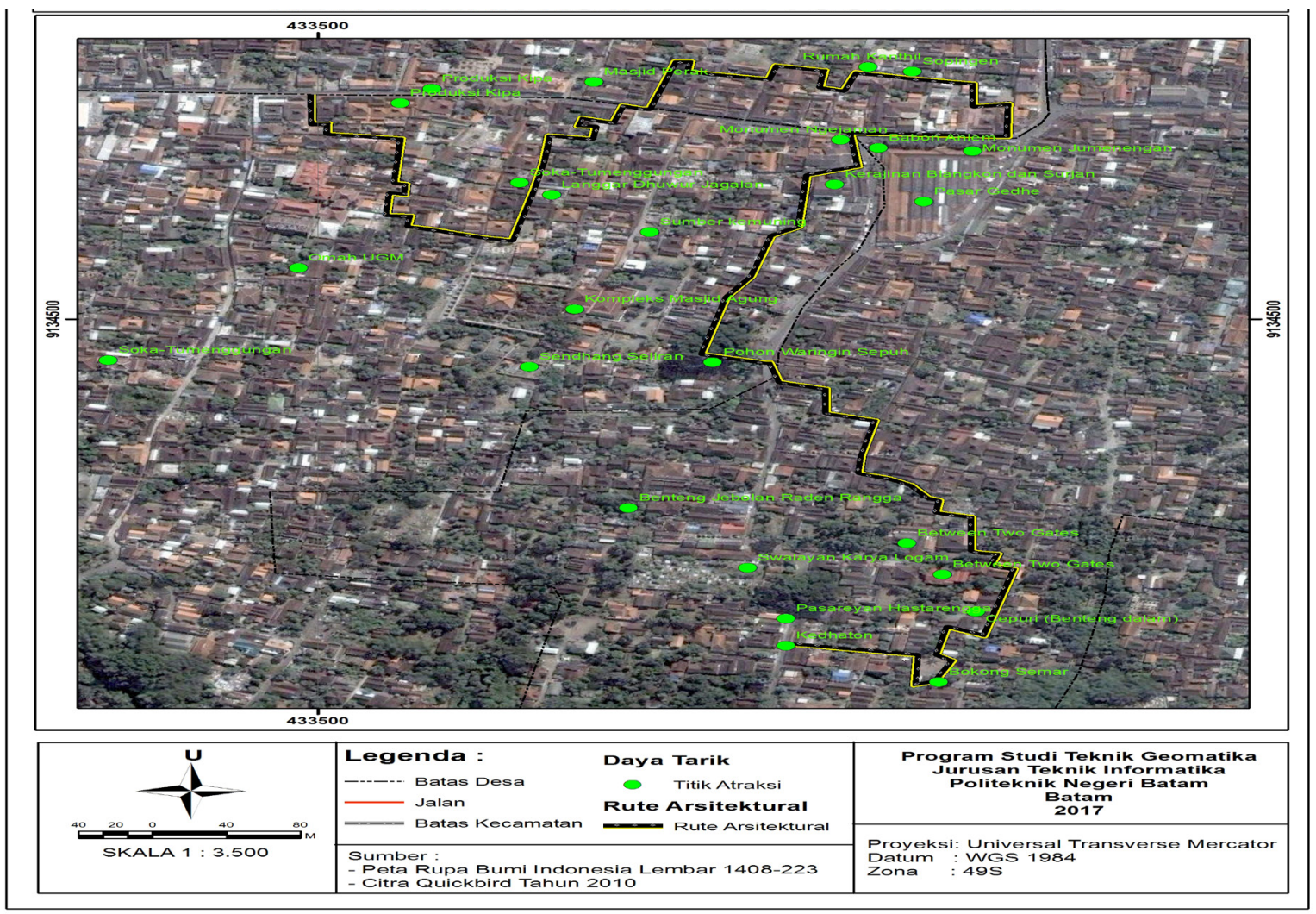

(Sumber: Analisis Data, 2017)

- Benteng Jebolan Raden Rangga - Kedhaton

- Cepuri (Benteng Dalam) - Between Two Gates - Dhondongan (gambar 6).

Keempat rute paket wisata jelajah tersebut dapat lebih jelas ditampilkan dalam peta rute jelajah pusaka Kotagede pada gambar 7 .

Hasil wawancara dengan pengelola menunjukkan bahwa tingkat partisipasi masyarakat adalah tinggi, karena seluruh perencanaan, pengelolaan, dan evaluasi dilakukan oleh masyarakat sendiri. Seluruh anggota dan kepengurusan berasal dari masyarakat sekitar dengan sistem kerja kekeluargaan. Musyawarah menjadi jalan keluar setiap terjadi masalah dengan melibatkan pengelola, pemandu, dan orang yang dituakan. Kegiatan jelajah cagar budaya ini mendapatkan dukungan dari masyarakat sekitar, pemerintah, dan stakeholder. Terbukti sampai saat ini kegiatan pengelolaan heritage trail masih terus berlangsung dan tidak ada penolakan dari warga.

Jelajah pusaka (heritage trail) bisa dilakukan dengan berjalan kaki maupun dengan sepeda onthel, tergantung permintaan dan jumlah pesertanya. Harga paket wisata menyesuaikan durasi, jumlah peserta, dan modifikasi sesuai permintaan wisatawan. Standar minimal 30 orang dengan biaya @ Rp. 35.000, sudah termasuk blusukan 3-4 jam dengan pemandu lokal, guidemap, air mineral $600 \mathrm{ml}$, bebas biaya masuk obyek berbayar, bebas mengambil gambar termasuk areal privat dalam rute. Untuk jumlah di bawah 30 orang bisa dibicarakan bersama pengurus, sesuai tema dan tujuan kunjungan. Untuk 
Wenang Anurogo, Muhammad Zainuddin Lubis, Hartono, Daniel Sutopo Pamungkas, Ahmad Prasetya Dilaga -- Ketahanan Kawasan Wisata Berbasis Masyarakat dalam Penguatan Ekonomi Lokal dan Pelestarian Sumberdaya Kebudayaan Kawasan Kotagede Yogyakarta

Gambar 6

Peta Rute Jelajah Studi Kecamatan Kotagede Yogyakarta

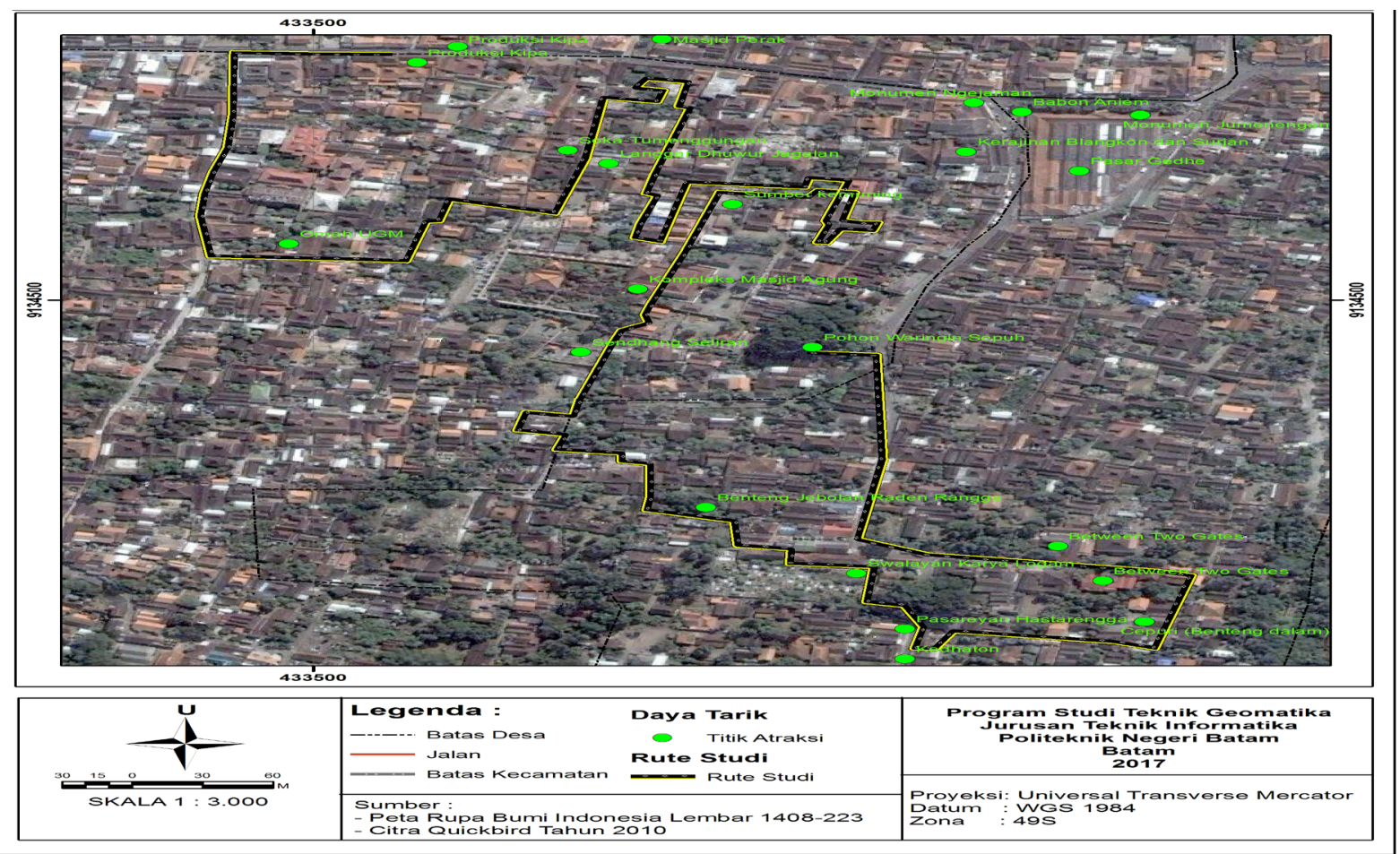

(Sumber: Analisis Data, 2017)

Gambar 7

Peta Rute Jelajah Pusaka Kecamatan Kotagede Yogyakarta
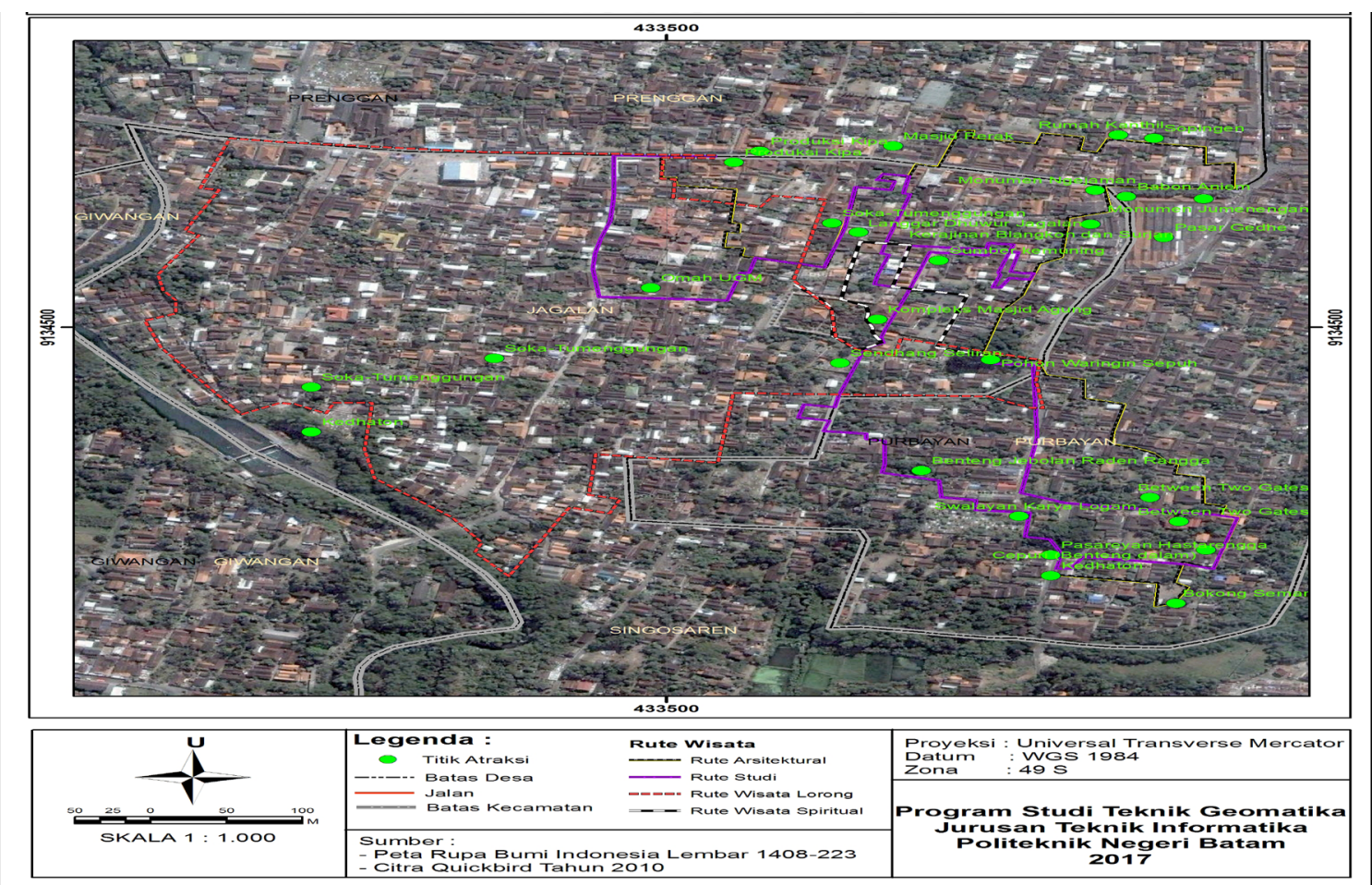

(Sumber: Analisis Data, 2017) 
Tabel 4

Tabel Harga Paket Jelajah Kotagede

\begin{tabular}{ll}
\hline \multicolumn{1}{c}{ Harga Jelajah Pusaka Kotagede } \\
\hline - Standar minimal 30 orang dengan biaya @35.000 & - blusukan 3-4 jam dengan pemandu local \\
& - guidemap \\
& - air mineral $600 \mathrm{ml}$ \\
& - bebas biaya masuk obyek berbayar \\
& - bebas mengambil gambar termasuk areal privat \\
& dalam rute. \\
& - Untuk wisatawan asing \\
& - Untuk sewa sepeda \\
& - Untuk paket makan siang \\
& - Untuk kelas menari atau membatik \\
& - Tidak termasuk biaya parkir \\
- Menambah@ Rp. 35.000 & - Asuransi \\
- Menambah@ Rp. 75.000 & - Pengeluaran pribadi \\
- Menambah@ Rp. 100.000 &
\end{tabular}

(Sumber: Analisis Data, 2017)

group besar maksimal konfirmasi H-3 dan DP 50\% dari total biaya. Tabel 4 adalah harga paket jelajah kawasan Kotagede, Yogyakarta.

Jelajah Pusaka Kotagede (Kotagede Heritage Trail) merupakan kegiatan wisata minat khusus berupa blusukan di dalam kampung-kampung Kotagede, sebuah bekas Kerajaan Mataram Islam yang tata kotanya masih terlihat merupakan kota lama. Perjalanan wisata budaya melalui 2 (dua) wilayah, yaitu Kabupaten Bantul dan Kota Yogyakarta. Dalam kegiatan ini, wisatawan diajak untuk menyusuri lorong-lorong kampung di Kotagede, melihat rumah-rumah tradisional berserta kehidupan sosial budaya yang secara turun temurun masih dilaksanakan oleh warga Kotagede, mencicipi kuliner khas Kotagede, melihat kesenian tradisional setempat yang dapat dinikmati dalam paket-paket wisata yang ditawarkan. Kegiatan Jelajah Pusaka Kotagede merupakan kegiatan komersial pemberdayaan masyarakat lokal Kotagede yang juga memiliki misi sebagai pembelajaran terhadap pusaka (heritage) Kotagede dengan memanfaatkan berbagai potensi pusaka (heritage) Kotagede.
Potensi-potensi yang terdapat di wilayah Kotagede telah diwujudkan dalam paketpaket wisata jelajah dengan berbagai macam modifikasi. Paket perjalanan dapat disesuaikan dengan permintaan wisatawan, hal ini juga bertujuan untuk memperkenalkan atraksiatraksi yang terdapat di wilayah Kotagede melalui paket wisata jelajah. Contoh paket wisata Jelajah Pusaka Kampung Wisata Prenggan (Paket Standar). Durasi perkiraan waktu 3 (tiga) jam. Rute awal berada di Kompleks Sopingen sebagai titik kumpul dan titik awal, karena memiliki halaman yang luas dan berada di pinggir jalan. Kompleks Sopingen (start) - Kerajinan Perak - Pendopo Kajengan - Masjid Perak - Lorong Ndarakan - Ndalem Proyodanan - Kuliner Kipo - Gang Soka Lorong Krintenan - Lorong Kanthil - Lorong Kudusan - Masjid Mataram - Pasar Lorong Pekaten - Kompleks Sopingen (finish). Rute standar ini dapat mengakomodir keseluruhan 4 (empat) paket yang direkomendasikan ke dalam satu rute perjalanan. Tempat-tempat yang dikunjungi mampu mewakili paket wisata jelajah spiritual, lorong, arsitektural, 
Wenang Anurogo, Muhammad Zainuddin Lubis, Hartono, Daniel Sutopo Pamungkas, Ahmad Prasetya Dilaga -- Ketahanan Kawasan Wisata Berbasis Masyarakat dalam Penguatan Ekonomi Lokal dan Pelestarian

Sumberdaya Kebudayaan Kawasan Kotagede Yogyakarta

dan studi, karena mengunjungi sebagian dari kekhasan masing-masing paket wisata jelajah untuk keseluruhan. Dalam rute awal atau akhir jelajah bisa ditambahkan berupa tradisional snack on the route $\neg$ lunch / dinner dengan menu ala Kotagede di rumah joglo, pertunjukan kesenian, workshop belajar membuat kerajianan/ kuliner dan sebagainya sebagai modifikasi dari paket.

Keempat paket wisata jelajah Kotagede yang telah direkomendasikan oleh pengelola dapat dikategorikan dalam paket studi dan non studi/wisata murni. Paket wisata jelajah studi ditekankan kepada pembelajaran terhadap heritage/pusaka, misal situs sejarah, arsitektur tradisional, makanan tradisional, kesenian tradisional yang ada di Kotagede dan sebagainya, baik berupa kunjungan biasa, pertunjukan maupun workshop/ kursus singkat. Untuk kegiatan seminar atau workshop yang terkait dengan pelestarian heritage/pusaka juga bisa diselenggarakan di pendopo-pendopo Kotagede dalam waktu tersendiri beserta fasilitas-fasilitasnya serta konsumsi dengan berbagai pilihan. Paket non studi ditekankan kepada kemasan bersifat yang lebih fun, seperti wisata lorong/labirin, melihat rumah-rumah tradisional dan situs pusaka/heritage dikombinasikan dengan pertunjukan kesenian maupun kuliner khas Kotagede.

Pengelolaan Kotagede dapat menjadi kawasan destinasi pariwisata unggulan. Keunggulan tersebut adalah memiliki potensi budaya, sejarah, kuliner dan keragaman arsitektur yang sangat menarik bagi wisatawan. Kotagede menawarkan ragam atraksi bagi wisatawan dan dapat diakses dari pusat Kota Yogyakarta dengan kendaraan umum atau kendaraan pribadi. Kelembagaan Kotagede telah menarik berbagai aktivis masyarakat untuk ikut merawat dan melestarikan cagar budaya agar dapat dijadikan tour wisata. Merealisasikan keunggulan utama perlu memperhatikan aspek keberadaan rumah dengan arsitektur Jawa, aspek pengembangan pariwisata, dan pengembangan ekonomi lokal. Karakteristik urban telah membawa banyak permasalahan, terutama yang bersifat fisik, baik yang diakibatkan oleh penduduk, maupun pemekaran kota. Cepat atau lambat peningkatan penduduk, pembangunan yang tak terkendali, sangat membahayakan keberadaan asset budaya yang ada di kawasan ini. Jaringan jalan di kawasan ini dirasa masih kurang mencukupi, karena terlalu sempit, dan tidak sesuai dengan beban kendaraan yang padat, mengingat kawasan ini merupakan kawasan tujuan wisata, sehingga perlu dilakukan revitalisasi atau pelatihan penanggulangan bencana.

Adapun potensi dan daya tarik pengelolaan kawasan cagar budaya Kotagede yang membuat para wisatawan tertarik untuk datang adalah (1). Dari segi historis keberadaan benda-benda budaya mempunyai keterkaitan sejarah dengan Kraton Yogyakarta. (2). Adanya potensi menciptakan tema/ citra kawasan tua dilihat dari sejarahnya sebagai bekas ibukota Mataram. (3). Adanya keragaman atraksi yang ditawarkan, meliputi potensi fisik (spasial-arsitektural) serta sosial kemasyarakatan yang tercermin dari lifestyle, upacara tradisi, kesenian, kerajinan, dan sebagainya. (4). Kedekatan dengan infrastruktur kota yang memudahkan aksesibilitas dan penyediaan prasarana dan sarana. (5). Potensi wisata budaya, baik dari segi kesejarahan, arsitektural, maupun ekonomi yang didukung adanya produkproduk kerajinan seperti kerajinan perak yang berkualitas ekspor. 
Kajian wisata kawasan Kotagede ini dapat dijadikan bahan dasar pengambil keputusan bagi steakholder terkait guna mengembangkan kawasan wisata tersebut. Kebijakan pembangunan berkelanjutan untuk kawasan cagar budaya Kotagede sebaiknya melibatkan masyarakat secara langsung dan melihat fakta di lapangan serta dapat menjalin kerjasama dengan pihak terkait seperti biro perjalanan, pemerintah (Dinas Pendidikan dan Pengajaran, Dinas Kebudayaan) sebagai rencana jangka pendek untuk memperkenalkan lebih luas kegiatan jelajah cagar budaya. Rencana jangka panjang untuk merencanakan pengelolaan jangka panjang yang saling berkaitan.

Wisata kawasan Kotagede ini dapat dikatakan menjadi ketahanan kawasan wisata berbasis masyarakat dalam penguatan ekonomi lokal serta dan pelestarian sumberdaya kebudayaan kawasan Kotagede Yogyakarta dilihat dari berbagai macam aspek.

Pertama, adalah aspek kebijakan upah yang diberikan kepada anggota Karang Taruna yang mengurusi jelajah wisata Kotagede ini. Dari situ para pemuda yang menjadi tour guide bisa mendapatkan pemasukan yang dapat mengurangi angka pengangguran para pemuda.

Kedua, adalah aspek ketahanan kawasan wisata berbasis masyarakat dalam penguatan ekonomi lokal dan pelestarian sumberdaya kebudayaan kawasan Kotagede Yogyakarta. Ini adalah aspek perdagangan, dengan adanya aktivitas wisata - wisata tersebut, masyarakat sekitar yang memanfaatkan untuk menjajakan makanan - makanan baik tradisional sampai dengan modern akan dapat imbas positif dengan semakin lakunya dagangan mereka, apalagi jika itu dimasukkan ke dalam salah satu destinasi dari rute wisata yang dilakukan. Aspek perdagangan ini dapat meningkatkan kesejahteraan masyarakat sekitar dengan menjadikannya sebagai mata pencaharian.

Ketiga, aspek perawatan dan rehabilitasi infrastruktur kawasan pembangunan oleh steakholder terkait baik swasta maupun pemerintah. Hal ini dapat menjadikan suatau kawasan wisata lebih bagus dan berkembang, sehingga meningkatkan kemauan dari wisatawan untuk datang ke tempat tersebut apabila infrastruktur sudah lebih memadahi.

\section{SIMPULAN}

Berdasar penjelasan tersebut di atas dapat ditarik simpulan sebagai berikut.

Pertama, atraksi wisata yang ada di kawasan Cagar Budaya Kotagede berupa benda-benda budaya, tradisi, kerajinan, dan kesenian dirangkum ke dalam 4 (empat) rute yang direkomendasikan yakni, paket wisata jelajah spiritual, paket wisata jelajah lorong, paket wisata jelajah arsitektural, dan paket wisata jelajah studi.

Kedua, Interaksi langsung bersama masyarakat Kotagede menjadi daya tarik wisatawan yang dapat dilakukan dengan cara menginap di rumah-rumah warga terutama di kawasan between two gates yang terkenal, dengan arsitektur, tata letak hingga tata ruang rumah yang dirancang dari jaman kerajaan. Wisatawan juga dapat ikut melihat hingga belajar proses pembuatan kerajinan hingga kuliner khas Kotagede. Jaringan jalan yang unik berupa jalan setapak yang berputarputar di antara padatnya permukiman, bahkan terdapat jalan yang melintasi halaman rumah warga sehingga membingungkan wisatawan hingga seperti akan terhimpit di antara labirin rumah-rumah menjadi daya tarik wisatawan.

Ketiga, pengelolaan tour wisata jelajah Kotagede Kelurahan Prenggan didominasi oleh kaum muda dengan usia produktif. Hal 
Wenang Anurogo, Muhammad Zainuddin Lubis, Hartono, Daniel Sutopo Pamungkas, Ahmad Prasetya Dilaga -- Ketahanan Kawasan Wisata Berbasis Masyarakat dalam Penguatan Ekonomi Lokal dan Pelestarian Sumberdaya Kebudayaan Kawasan Kotagede Yogyakarta

ini dapat diketahui dari sebagian pemandu yang masih berstatus sebagai mahasiswa. Kegiatan ini menjadi kegiatan sekunder pemuda selain aktivitas perkuliahan dan keagamaan (khususnya saat bulan Ramadan). Kegiatan ini berbasis masyarakat, mulai dari perencanaan kegiatan, pra kegiatan, hingga evaluasi kegiatan dilakukan oleh masyarakat. Stakeholder dan pemerintah bersifat pasif dengan memberi bantuan secara tidak langsung berupa ijin kegiatan, penyuluhan dari dinas terkait, bantuan dana, dan pelatihan.

\section{DAFTAR PUSTAKA}

Andayani, A. A. I., Martono, E., \& Muhamad, M. (2017), Pemberdayaan Masyarakat Melalui Pengembangan Desa Wisata Dan Implikasinya Terhadap Ketahanan Sosial Budaya Wilayah (Studi Di Desa Wisata Penglipuran Bali). Jurnal Ketahanan Nasional, 23(1), 1-16.

Anurogo, W., Lubis, M. Z., Khoirunnisa, H., Pamungkas, D. S., Hanafi, A., Rizki, F., ... \& Lukitasari, C. A. (2017), A Simple Aerial Photogrammetric Mapping System Overview and Image Acquisition Using Unmanned Aerial Vehicles (UAVs). Journal Of Applied Geospatial Information, 1(01), 11-18.

Armawi,A., \& Muhamad, M.(2016), Partisipasi Pemuda Dalam Mengembangkan Pariwisata Berbasis Masyarakat Untuk Meningkatkan Ketahanan Sosial Budaya Wilayah (Studi di Desa Wisata Pentingsari, Umbulharjo, Cangkringan, Sleman, DI Yogyakarta). Jurnal Ketahanan Nasional, 22(2), 137-157.

Baiquni, M. (1998), Membangun pusat di pinggiran: pengembangan wilayah melalui kerjasama ekonomi regional ASEAN.
Jurnal Kebijakan dan Administrasi Publik, 2(1998).

Gafara, C., Riyono, B., \& Setiyawati, D., Peran Karang Taruna Dalam Pemberdayaan Penyandang Disabilitas Di Desa Karangpatihan, Kabupaten Ponorogo Dan Implikasinya Terhadap Ketahanan Ekonomi Keluarga. Jurnal Ketahanan Nasional, 23(1), 37-48.

Handayani, G, \& Priyono, K. D. (2016), Evaluasi Potensi Kawasan Kotagede Sebagai Destinasi Wisata Berbasis Warisan Budaya (Heritage Tourism) Daerah Istimewa Yogyakarta, Disertasi, Universitas Muhammadiyah Surakarta.

Margono, S. (2000), ADR, Alternative Dispute Resolution, \& Arbitrase: Proses Pelembagaan dan Aspek Hukum. Jakarta, Ghalia Indonesia.

Mikkelsen, A., \& Saksvik, P. Ø. (1999), Impact of a participatory organizational intervention on job characteristics and job stress. International Journal of Health Services, 29(4), 871-893.

Octaviano, B. C. (2013), Kualitas Produk Wisata Arsitektural Dikawasan Kotagede Yogyakarta, Disertasi, Universitas Gadjah Mada.

Rahmi, Y. N. (2011), Perencanaan Lanskap Wisata Pada Kawasan Cagar Budaya Kotagede, Yogyakarta.

Ristiyanti, E. (2008). Strategi Pengembangan Wisata Alam Berbasis Masyarakat: Studi Kasus Di Zona Pemanfaatan Taman Nasional Gunung Merapi Daerah Istimewa Yogyakarta.

Saleh, I. N. S., \& Hardjasoemantri, H. K. (2004), Kajian Aspek Hukum Konservasi Cagar Budaya Terhadap Pelestarian Dan 
Pengembangan Pariwisata Kotagede, Disertasi, Universitas Gadjah Mada.

Strauss, A., \& Corbin, J. (1990) Basics of qualitative research (Vol. 15). Newbury Park, CA: Sage.

Suprihanto, J., \& Armawi, A. (2016). Strategi Pengembangan Wirausaha Pemuda Dalam Mewujudkan Wirausahawan Mandiri Dan Implikasinya Terhadap Ketahanan Ekonomi Keluarga (Studi pada Koperasi Sumekar di Kampung Sanggrahan Pathuk Kecamatan Ngampilan Kota Yogyakarta, Provinsi Daerah Istimewa Yogyakarta). Jurnal Ketahanan Nasional, 22(1), 42-60.

Smylie, M. A., Lazarus, V., \& BrownleeConyers, J. (1996). Instructional Outcomes of School-based Participative Decision Making. Educational evaluation and policy analysis, 18(3), 181-198.

Yusuf, I. F., Martono, E., \& Prasetya, A. (2016), Peran Pemuda Dalam Pengembangan Eduwisata Energi Terbarukan Dan Implikasinya Terhadap Ketahanan Ekonomi Wilayah (Studi di Desa Poncosari Kecamatan Srandakan Kabupaten Bantul Daerah Istimewa Yogyakarta). Jurnal Ketahanan Nasional, 22(3), 285-305. 